\title{
INTERPERSONAL FUNCTION IN MAHER ZAIN"S SONG LYRICS “PALESTINE WILL BE FREE”
}

\author{
By: Rayendriani Fahmei Lubis, M.Ag., Hamka, M.Hum., and Mukarromah
}

\begin{abstract}
Abstrak
Penelitian ini membahas tentang fungsi interpersonal dalam lirik lagu Maher Zain "Palestina akan bebas". Akan lebih mudah dan lebih menarik untuk menganalisa fungsi interpersonal melalui karya sastra yang orang dengar setiap hari seperti lirik lagu. Tujuan dari penelitian ini adalah untuk mendeskripsikan fungsi interpersonal, untuk mengetahui jenis mood, untuk menjelaskan jenis mood yang digunakan dalam lirik lagu "Palestine akan bebas". Jenis penelitian ini adalah deskriptif kualitatif dengan menggunakan metode kualitatif, menggunakan analisis isi. Sumber utama data dalam penelitian ini adalah lirik lagu "Palestine will be free". Analisis data menggunakan langkah-langkah berikut: pertama, mengumpulkan data dalam bentuk klausa. Kedua, mengklasifikasi. Ketiga, analisis mood dan residu. Keempat, menganalisa tipe mood. Yang terakhir, menarik kesimpulan. Berdasarkan hasil penelitian, struktur fungsi interpersonal memberikan pemahaman yang lebih lengkap. Tipe mood bersifat deklaratif, interogatif, imperatif. Suasana deklaratif lebih banyak digunakan dalam lagu ini. klausa deklaratif dalam lirik lagu "Palestina akan bebas" berfungsi sebagai pernyataan untuk memberi sebanyak mungkin informasi kepada pembaca atau pendengar. Hal ini didukung oleh lagu yang mengandung makna.
\end{abstract}

Key words: Fungsi Interpersonal

\section{Introduction}

Actually, a song contains music and lyric. Music is called the language of emotions. Music can be a tool to share feeling between human beings. There are human beings who choose the music to express and share their own feeling because human beings have sense of music. The language of music or the lyric will describe the singer's feeling. The lyrics fit the music and the music fit the lyrics and together they form a complete unit. Implicitly, musicians create music not only to entertain but also to communicate through expressing, deliver or sharing his/her own feeling to others. Human beings create music to share his feeling whether it is sad or happy.

The songs that show the composers's feeling can be heard from one of the phenomenal singer, Maher Zain. He is a British-Muslim, he is the new star of 
modern Islamic music with his meaningful songs that the aim is to inspire and entertain people and send a message of peace and hope to the world. One of the his songs is "Palestine Will Be Free". This song invites people to care about Palestine that occupied by Israel. From above explanation the researcher wants to know the meaning in song lyrics "Palestine Will Be Free" if it is seen from linguistic side. So let to see from linguistic side. Metafunction are analysis of text and context function. By the function of human's life, the language all at once called function in communication, that is exchange the experience who technically named Interpersonal function.

This analysis is carried out based on systemic functional linguistics approach. This research focuses on the interpersonal relationship that can be seen through the interpersonal function realized on the song's lyrics. The researcher conducts a linguistic research on interpersonal function analysis in song lyrics "Palestine Will Be Free".

Interpersonal function is meaning as a form of action, the speaker or writer share something to the listener or reader by means of language. Interpersonal function are meanings of expression from a speaker's attitude or judgment. The elements of interpersonal function are Mood and Residue. Mood elements carry the interpersonal function of the clause and consist of subject and finite. The other element is called the Residue. Residue consists of predicate, compliment, or adjunct.

Based on the phenomenon above, the researcher would like to see the interpersonal function in song lyrics "Palestine Will Be Free". Hopefully this analysis will give something new to behave. If the researcher connects interpersonal function and also applies to the song lyrics "Palestine Will Be Free", the researcher thinks this research will give a new contribution in life. So that is why this research is Interpersonal Function in Maher Zain's Song Lyrics "Palestine Will Be Free" $^{\prime \prime}$.

\section{B. The Objective of The Research}

Based on the formulation of the problems above, researcher aim to:

1. To describe the interpersonal function in song lyrics "Palestine Will Be Free ".

2. To find the types of Mood in song lyrics "Palestine Will Be Free". 
3. To explain the reason types of Mood used in song lyrics "Palestine Will Be Free ".

\section{Conceptual Study}

\section{Interpersonal Function}

\section{a. Interpersonal Function as One of Metafunction}

Metafunction refers to the systematic functional linguistic. Metafunction of language is the function language in using language by the speaker. The language is analyzed into three board metafunctions those are ideational function, interpersonal function, and textual function. ${ }^{1}$ Metafunctions are grammars based human experience on representation (Experiential), exchange (Interpersonal), organizing (Textual), and relationships (Logical). It is called grammar is theory of experience, how the experience described, exchanged, assembled and linked. Form of experience contained clause, because clause isa grammatical unit as form of experience. The ways in which human beings use language are classified in SFL into three broad categories known as metafunctions, there are ideational metafunction, interpersonal metafunction and textual metafunction. ${ }^{2}$

1) Ideational function is about things and ideas that are realized in the clause. Ideational function is distinction into experiential and logical. The experiential is largely concerned with content or ideas. The logical is concerned with the relationship between ideas.

2) Interpersonal function is a way of acting, function of language is to fulfill human needs in exchange of experience. Interpersonal function is related with expressing an opinion through the use of modality.

3) Textual function is clause as a unit of message, organization message, and relevance to context (linguistic and social). Textual function is realized through the word order of the sentences, through which the writer orders the message for the reader. ${ }^{3}$

${ }^{1}$ M. A. K. Halliday and Christian M.I.M. Matthiessen, An Introduction to functional Grammar (London Edward Arnold, 1985), p. 7.

${ }^{2}$ Thomas Bloor and Meriel Bloor, The Functional Analysis of English Second Edition (London: Arnold, 2004 ), p. 10.

${ }^{3}$ Ibid. 
Based on the explanation above, metafunction refers to three, there are ideational function, interpersonal function and textual function. In this case the researchers only be analyzed on interpersonal function because of the limitations of cost, time and ability which is owned byresearcher own. The following will be explained about the interpersonal function in maher zain song.

\section{b. The Definition of Interpersonal Function}

Thomas Bloor \& Meriel Bloor, they state that the language is used to enable us to participate in communicative acts with other people, to take on roles and to express and understand feelings, attitude and judgments, it is called interpersonal function Interpersonal function has to do with the ways in which we act upon one another through languagegiving and requesting information, getting people to do thing and offering to do thing ourselves -and the ways in which we express our judgment and attitudes. ${ }^{4}$

From the theories, the researcher can find the definition of interpersonal function is concerned with enacting interpersonal relations or expression of human using language to exchange information and using it to exchange goods and service. It means, the using of language may refer to cognitive ability to learn and use systems of communication, or to describe the set rules that makes up systems, or the set utterances that can be produced from thus rules. Language is simultaneously used as representation, exchange and organization of experience, as a social being, human kinds cannot live isolated, they need to interact with others in order to fulfill their needs, and they use language to express and give information and exchange their experience to others.

\section{c. The Component of Interpersonal Function}

The analysis of interpersonal function deals with two components, there are Mood element and Residue element of the clause.

${ }^{4}$ Graham Lock, Functional English Grammar An Introduction for second language teacher (Australia: Combridge University Press, 1996), p. 9. 
1) Mood

Subject and finite are closely linked together and combine to form one constituent which call the Mood. The Mood is the element that realizes the section of Mood in the clause. It has sometimes been called the modal element, but the difficulty with this is that term modal is ambiguous, since it corresponds both to Mood and to modality. ${ }^{5}$ Mood is the mode or manner in which the action denoted by verb is represented. ${ }^{6}$ Mood consists two elements, there are subject and finite.

2) Residue

a) Predicator

The predicator is realized by the non-tensed (or nonfinite) elements or elements of the verbal group. Angela Downing states that the predicator is identified syntactically by position and concord. ${ }^{7}$ Halliday states that the predicator is present in all major clauses, except those where it is displaced through ellipsis. It is realized by a verbal group minus the temporal or modal operator. ${ }^{8}$ It means, the predicator is the explanation of subject, association of meaning expression of tense, aspect, modality, voice and phrase realize by nominal group. Example:

John drives too fast.

My mother has gone to the rice field.

b) Complement

The complement is typically realized by nominal groups, it is an element within the residue. The complement is the constituent necessary to complete the predicator in sentence. In grammar the complement is called the object of sentence,

\footnotetext{
${ }^{5}$ M.A.K. Halliday, An introduction to functional Grammar Second Edition (London: Edward Arnold, 1994), p.74.

${ }^{6}$ Wren and martin, high school english grammar and composition, 1990.p. 74. 2002). P. 31.

${ }^{7}$ Angela Downing and Philip Locke, A University Course In English Grammar (New York,

${ }^{8}$ M.A.K. Halliday(1994),Of. Cit. p.79.
} 
usually the complement can find after predicate because the function of complement is to complete the predicator. It is defined as a non-essential participant in the clause, a participant somehow affected by the main argument of the preposition. It is also defined as an element within the residue that has the potential of being subject but is not. ${ }^{9}$

Example:

I am reading book.

She looks the picture.

3) Adjunct

The final constituents that we need to describe are the adjunct. It can be defined as clause elements which contribute some additional information to the clause. Adjunct is an element that has not got the potential of being subject. It is realized by an adverbial or a propositional phrase. ${ }^{10}$ It means, the adverbial or propositional phrase in a sentence as adjunct in interpersonal function, example:

She drank milk last morning.

I went to Medan yesterday.

Yesterday is an adverb of time, so yesterday is adjunct in interpersonal function. Another example that uses propositional phrase: a fish is eaten by cat. By cat is adjunct.

Table 1. The Mood Types

$\begin{array}{lll}\text { Communicative act } & \text { Mood } & \text { Example } \\ \text { Making a statement } & \text { Declarative } & \text { I have a cat. } \\ \text { Asking a question } & \text { Interrogative } & \text { Did you have a cat? } \\ \text { Giving a directive } & \text { Imperative } & \text { Have a cat! }\end{array}$

${ }^{9}$ M A K. Halliday, 2004( Of. cit).p. 122.

${ }^{10}$ M.A.K. Halliday(2004),Ibid . p. 123. 
While, mood structure is a clause structure which realizes an interpersonal function. The interpersonal function concerns the relationship or interaction among participants, which can be classified into two giving and demanding. These interactions related to the nature of commodity being exchanged: good and services or information. WHelement is the subject, and finite before subject otherwise.

The explanation of Mood structure can be seen the table below:

Table 2. Mood Structure

$\begin{array}{llll}\text { Mood } & \text { +/-Subject } & \text { Order } & \text { Example } \\ \text { Declarative } & + \text { Subject } & \text { Subject + Finite } & \text { Budi studies. } \\ \text { Interrogative(yes/no) } & \text { + Subject } & \text { Finite + Subject } & \text { Does Budi study? } \\ \text { Interrogative }(\mathrm{WH}) & + \text { Subject } & \text { WH+ Finite + Subject } & \text { What does Budi study? } \\ \text { Imperative } & \text {-Subject } & \text { Predicator } & \text { Study! }\end{array}$

More, Halliday states that there are two basic interactive distinctions. The first distinction is between using language to exchange information and using it to exchange good and services. The second distinction is between demanding and giving. ${ }^{11}$ The two interactive distinctions define the four main types of speech function as to form our communication in daily life. The four primary speech functions of offer, command, statement, and question. These, in turn, are matched by a set of desired responses: accepting an offer, carrying out a command, acknowledging a statement and answering a question. ${ }^{12}$ These four speech functions are usually used in our conversation. See the table below.

Table 3. Speech Function

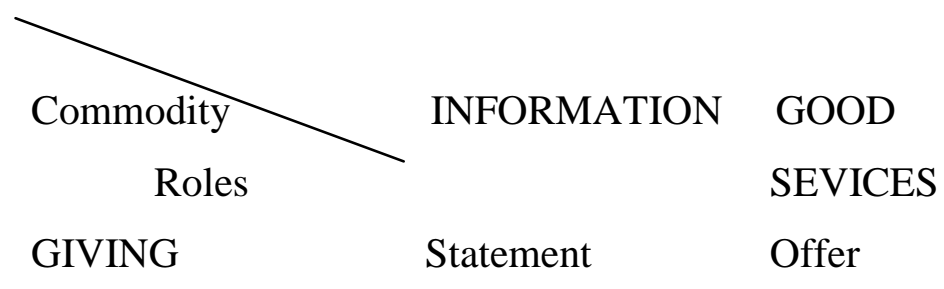

AND

${ }^{11}$ M.A.K. Halliday(1994) Of. Cit, p.68.

${ }^{12}$ Ibid, p. 69 
DEMANDING Question Command

Halliday formulates the semantics of interpersonal metafunction along two axes, that is, the axis of "role in exchange", either giving or demanding, and the axis of "commodity exchanged", either goods- $\&$ services or information. These two dimensions give four speech functions of "offer" (i.e. giving goods- $\&$-services), "statement" (i.e. giving information), "command" (i.e. demanding goods-\&-services), and "question" (i.e. demanding information).

Speech function is more oriented to functional, interpretation, specifically to systemic functional one. When the roles and commodity are intersected or cross classified with reference to systemic functional linguistic theories.

1) [giving/information $]=$ statement.

2) $[$ demand $/$ information $]=$ question.

3) $[$ giving/goods $\&$ services $]=$ offer.

4) $[$ demand $/$ goods $\&$ services $]=$ command.

\section{d. The Biography of Maher Zain}

Maher Zain is a singer and song writer. Maher Zain is the new star of modern islamic music with his meaningful songs that the aim is to inspire and entertain people and send a message of peace and hope to the world. Maher Zain is a Muslim Swedish R\&B singer, song writer and music producer of Lebanese origin. Maher zain got his first keyboard when he was only ten and ever since music officially became part of Maher's world.

His family moved to Sweden when Maher was only 8, where he continued his schooling, and later entered university and got a Bachelors degree in Aeronautical Engineering. With things changing around him, one thing remained the same - his strong passion for music. He would spend late nights at school with his friends where they would sing, rap, compose and experiment with music in every way. It didn't take him long to realize that music became an integral part of who he is. music was 
something he had loved from a young age and he didn't want to abandon it. Instead, he made a transition: he swapped secular music for something more religious. ${ }^{13}$ The complete profile of Maher Zain can see below:

Name

Date of birth

Nationality

Education

Job

Debut Album Name

Number of Tracks

Date

Record Label

Name

Release Date

Number of Tracks

Record Label

Website

Record Label

Facebook Page

Twitter Page
: Maher Zain

: March 16, 1981 in Tripoli

: Swedish (of Lebanese origin)

: BA in Aeronautical Engineering Previous

: Music Producer

: Thank You Allah

: 13 Release

: 1st of November 2009

: Awakening Records Second Album

: Forgive Me

:2nd of April 2012

$: 14$

: Awakening Records

: www.maherzain.com

: Awakening Records www.awakening.org

: http://www.facebook.com/MaherZain

: http://twitter.com/MaherZain

Artists like Maher zain has tapped into an important need in the Muslim community to have music that reflects his religious commitment. Even if all Muslims do not appreciate his music because of he use of instruments (some Muslims believe that only the voice and a specific type of percussion can be used for music), his music offers young Muslims an alternative that they can relate to became the best men and women.

\section{e. The Song Lyrics "Palestine Will Be Free"}

Grolier states that the song is a short musical work set a poetic text with equal importance given music and to the words. Song is a short

\footnotetext{
${ }^{13}$ Eena Houzyama. Thanks God for Maherzain ( http://en.wikipedia.org/wiki/maherzain. Accessed at April 1, 2016 retrieved on $5 \mathrm{pm}$ )
} 
metrical composition intended for singing, esp. one in rhymed ; a lyric; a ballad. Lyric are the composition in verse which is sung to a melody to constitute a song. Lyric is expressing deep personal emotion or observation. ${ }^{14}$ Merriam Webster states that the song is a melody for a lyric poem or ballad. ${ }^{15}$ It means, the song is a lyric that has several stanzas, each stanza usually consists of four lines and sometimes a verse composed of three lines, it depends writer. Every stanzas is written in a song always has a specific meaning so as to create a happy song, a sad song and others.

Song "Palestine will be Free" is sung by Maher Zain. The lyrics, melody are made by Maher Zain. It can get from album Thank You Allah. ${ }^{16}$ The song was inspired by the Israeli atrocities against the Palestinians more and more casualties, but the Palestine still struggling to maintain the dignity of the state and religion. The lyric of "Palestine will be Free" can be seen below:

Every day we tell each other That this day will be the last And tomorrow we all con go home free And all this will finally end Palestine tomorrow will be free] $2 x$

No mother no father to wipe away my tears

That's why I won't cry

I feel scared but I won't show my tears

I keep my head high

Deep in my heart I never have any doubt that

Palestine tomorrow will be free] $2 x$

I sow those rockets and bombs shining in the sky

Like drops of rain in the sun's light

Taking away everyone dear to my heart

Destroying my dreams in a blink of an eye

What happened to our human rights

What happened to the san city of life

And all those other lies

I know that I'm only a child

But is your conscience still alive

Ooooooh yeaaah

${ }^{14}$ http://Eprints.walisongo.ac.id accessed on 22/10/2016. 14.25. P.M.

15 http://www.merriam-webster.com/lyric accessed on 22/10/2016.14.15 P.M.

${ }^{16}$ http://sahabatkecilku.blogspot.co.id accessed on 28/12/2016.20.13 P.M. 
I will caress with my bare hands

Every precious grain of sand

Every stone and every tree

Cause no matter what they do

They can never hurt you

Cause your soul will always be free

Palestine tomorrow will be free] $2 x$

The song lyrics "Palestine will be Free" tell about prayer and hope

for the freedom of the people in Palestine. Inside this song also tells a hope that is in every people of Palestine as well as all peoples, that one day there will be freedom and peace for their dreams.

In the first verse of this song tells the beliefs and desires of the Palestinian people free from insurgency and Israeli atrocities. The next verse describes the grief they are experiencing, but sadness that requires them to become stronger and keep fighting. In this song reef that Palestine is illuminated by rockets and bombs that destroyed the dreams, hopes, human rights, the san city of life of the people in Palestine. And the end of this song tells that the people of Palestine do not ever give up. Despair, no fear, only faith and the struggle for the freedom of Palestine.

\section{Methodology of the Research}

\section{The Kind of the Research}

Qualitative research is the research which understanding the phenomenon based on the collection data and analysis of non-numerical data. The method of this research used qualitative descriptive. The goal of qualitative descriptive studies is a comprehensive summarization, in every day terms, of specific events experience by individuals or groups of individuals.

This research used content analysis. Content analysis is a study that is depth discussion of the content of written or printed information in mass media. Syukur kholil states that the manifest coding is "analisis isi yang di dasarkan pada kata-kata atau kalimat, gambar, symbol, yang dinyatakan secara explicit dalam teks". ${ }^{17}$ It means that coding manifest coding is based on content analysis to words or sentence, picture, symbol, expressed by explicit in a text. So, this research is done by qualitative descriptive and use content analysis.

\footnotetext{
${ }^{17}$ Syukur Kholil, Metode Penelitian Komunikasi,(Bandung: Ciptapustaka Media, 2006), p. 52.
} 


\section{The Data Source}

Bogdan \& Biklen state that the data on official documents including memos of meetings, policy documents, books, code of ethics, proposals, student statement of philosophy, new releases. ${ }^{18}$

The source of the data used in this research is Maher Zain song lyrics Palestine will be free. The data are in the form of clauses in the lyrics. The research will involve lyrics of Palestine will be free that taken from internet by researcher. The song lyric as a document to analysis.

\section{Technique of Data Analysis}

In this research, the researcher employed the content analysis in written words of Maher Zain song lyrics Palestine will be free to find the analysis of the interpersonal function. The followings were the steps of the data analysis of this study:

a. Collecting the data in the form of clauses from Maher Zain song lyrics Palestine will be free.

b. Classifying and choosing the song lyrics based on the relevance theme that is internal conflict happening to the writer in facing the life.

c. Analyzing the mood and residue of those Maher Zain song lyrics Palestine will be free.

d. Analyzing the mood types of Maher Zain song lyrics Palestine will be free.

e. Drawing the conclusion.

\section{The Location and Time of The Research}

${ }^{18}$ Bogdan, R.C. \& Biklen, S.K. Qualitative Research in Education: An Introduction to Theory and Method (Boston: Allyn \& Bacon, 1982) p. 304. 
This research will be do through wathcing the vidio of Maher Zain. The location of research at the building house Padangsidimpuan. The time of the research at 19 September 2016 until 11 October 2017.

\section{E. The Conclusion}

The conclusion of this research is drawn based on the findings and discussion as the following.

1. Interpersonal meaning of song lyrics "Palestine Will Be Free " is realized in the wordings of the clauses based on the Mood (subject, finite) and Residue (predicator, complement, adjunct) element.

2. There are three mood types namely imperative, interrogative and declarative. Based on the analysis of lyrics "Palestine will be free" the Mood Types used is Declarative Mood (93,4\%), while the second place is Interrogative Mood (6,6\%), and there is no Imperative Mood (0\%).

3. The declarative mood is more used in the lyrics "Palestine will be free" because typically of declarative was subject + finite, and there were functioned as statements to give as much as possible information to the reader or listener. It was employed to give information to the listeners or readers that the Palestine possibility to be free. two clauses were interrogative because typically of interpersonal function was finite + subject, and there were functioned as question, it was employed that Palestine demand information.

\section{REFERENCES}

Angela Downing and Philip Locke, A University Course In English Grammar, New York, 2002.

A.S. Homby, Oxford Learner's Pocket Dictionary Fourt Edition, New York: Oxford University Press, 2000.

Ardial, Paradigma dan Model Penelitian Komunikasi, Jakarta: Bumi Aksara, 2014.

Arikunto, S. Prosedure penelitian:suatu pendekatan prakter. jakarta: rineka cipta, 2002. 
Bogdan, R.C. \& Biklen, S.K. Qualitative Research in Education: An Introduction to Theory and Method, Boston: Allyn \& Bacon, 1982.

Graham Lock, Functional English Grammar An Introduction for second language teacher, Australia: Combridge University Press, 1996.

Harimurti Krisdalaksana, Kamus Linguistik, Jakarta: PT. Gramedia Pustaka Utama, 2001.

Jayanthi Dakshina Murthy, Contemporary English Grammar, New Delhi: Book Palacc. 2003.

John S. Hartanto dkk, accurate, brief and clear English Grammar, Surabaya:penerbit Indah surabaya, 2003.

Linda Gerot and Peter Wignell, Making Sense Of Functional Grammar, Australia: Gerd Stabler, 1994.

Lise Fontaine, Analysing English Grammar a systematic functional introduction New York: Cambridge University Press,2013.

M.A.K.Halliday and Christian M.I.M. Matthiessen, An Introduction to functional Grammar, London Edward Arnold, 1985.

M.A.K. Halliday and Christian M.I.M. Matthiessen, An introduction to functional Grammar, London: Edward Arnold, 1999.

M.A.K. Halliday, An introduction to functional Grammar Third Edition, London: Edward Arnold, 2004.

M.A.K. Halliday, An introduction to functional Grammar Second Edition, London: Edward Arnold, 1994.

Macella Frank, Modern English A Practical Reference Guide, America: Prentica-Hall, 1972.

Mardalis, Metode Penelitian Suatu Pendekata Proposal, Jakarta: PT Bumi Aksara, 2003.

Moh. Kusnadi, complete English Grammar, Surabaya: Bintang Usaha Jaya, 2011.

Nana Sudjana, Tuntunan Penyusunan Karya Ilmiah, Makalah, Skripsi,Thesis, Disertasi, Bandung: Sinar Baru Algesiko, 2003.

Nana Sysodih Sukmadinata, Metode Penelitian Pendidikan, Bandung: PT Remaja Rosdakarya, 2010.

Nanda. An Analysis Of Interpersonal Function In Mario Teguh Facebook Status, Script Student University of Medan. 
Ridwana , Experiential Function In Maher Zain Song Lyrics 'Guide Me All The Way script of Student in IAIN Padangsidimpuan, 2016.

Rowiatun Amri Marhamah. Interpersonal Meaning Analysis Of Musa Song Lyrics In Black Holes And Revelations' Album, (A Study Based On Systemic Functional Linguistics, Script of Student University of Yogyakarta. 2014.

Satrio Nugroho, Practical complete English Grammar, Surabaya: Kartika.

Shakila nur, The International Journal of social sciences. Department of English, Faculty of Languages and Translation King Khalid University, Abha, Saudi Arabia, $30^{\text {th }}$ January 2015.vol.30 No.1.

Suharsimi Arikunto, Manajemen Penelitian, Jakarta: PT Rineka Cipta, 2010.

Thomas Bloor and Meriel Bloor, The Functional Analysis of English Second Edition, London: Arnold, 2004.

Wren and martin, high school english grammar and composition, 1990.

Eena Houzyama. Thanks God forMaherzain(http://en.wikipedia.org/wiki/maherzain).

http://Eprints.walisongo.ac.id

http://www.merriam-webster.com/lyric accessed on 22/10/2016.14.15

http://sahabatkecilku.blogspot.co.id 